\title{
Primeiro relato de Lembosia bromeliacearum var. stellulata (Asterinaceae) em Vriesea carinata (Bromeliaceae)
}

\author{
Olinto L. Pereira ${ }^{1}$, Paula T. C. Castroํㅡ, Robert W. Barreto ${ }^{1}$
}

\begin{abstract}
'Departamento de Fitopatologia, Universidade Federal de Viçosa, CEP 36571-000, Viçosa, MG. E-mail: liparini@ bol.com.br Autor para correspondência: Olinto L. Pereira

Data de chegada: 17/12/2005. Aceito para publicação em: 15/07/2006.
\end{abstract}

Durante um estudo da micobiota associada a algumas plantas epífitas do Parque Estadual do Rio Doce, um ascomiceto bitunicado, pertencente à família Asterinaceae, foi encontrado colonizando folhas da bromélia Vriesea carinata Wawra. O fungo possue as seguintes características morfológicas: colônias em folhas com diâmetro de 3-6 mm, de coloração negra; micélio interno ausente; hipostroma ausente, micélio externo marrom escuro, 2,5 - 5,0 $\mu \mathrm{m}$ diâm., com hifopódios capitados laterais 7,5-10,0 x 5-10 $\mu \mathrm{m}$, setas ausentes; ascomas ascostromáticos, superficiais, lineares a elipsóides, arranjados em forma estrelar (Figura 1A), localizado na superfície adaxial das folhas, $70-369 \mathrm{x}$ $70-229 \mu \mathrm{m}$, com deiscência por ostíolo longitudinal (Figura 1B), com abertura por ruptura e parede composta por células escuras e espessas; pseudoparáfises presentes, 2,5 $\mu \mathrm{m}$ diâm., filiformes, septadas, hialinas; ascos bitunicados (Figura 1C), 12,5 - 50,0 x 7,5 - 25,0 $\mu \mathrm{m}$, oval a ovóide, paralelos, com 8 ascósporos por asco; ascósporos didimosporos, $25-30 \times 6-7 \mu \mathrm{m}$, hialinos a marrom escuros e lisos (VIC 27796). Anamorfo ausente. As características morfológicas permitiram a identificação do fungo como sendo Lembosia bromeliacearum Rehm. var. stellulata Rehm., fitopatógeno relatado somente em espécies da família Bromeliaceae (Theissen, F., Annales Mycologici, v.11, p.425467, 1913). Essa variedade difere da variedade bromeliacearum pelo arranjo estrelar dos ascomas, encontrado apenas em $L$. bromeliacearum var. stellulata (Figura 1A). Na América do Sul, L. bromeliacearum var. stellulata é relatado em Aechmea sp., Tillandsia sp., Vriesea sp. e Vriesea glutinosa (Viégas, A.P., Índice de fungos da América do Sul. 1.ed. Campinas: Instituto Agronômico, 1961. 920p.). Portanto esse é o primeiro relato desse fitopatógeno na espécie $V$. carinata.

Agradecimentos ao Parque Estadual do Rio Doce pelas facilidades de acomodação e ao CNPq pelo apoio financeiro.

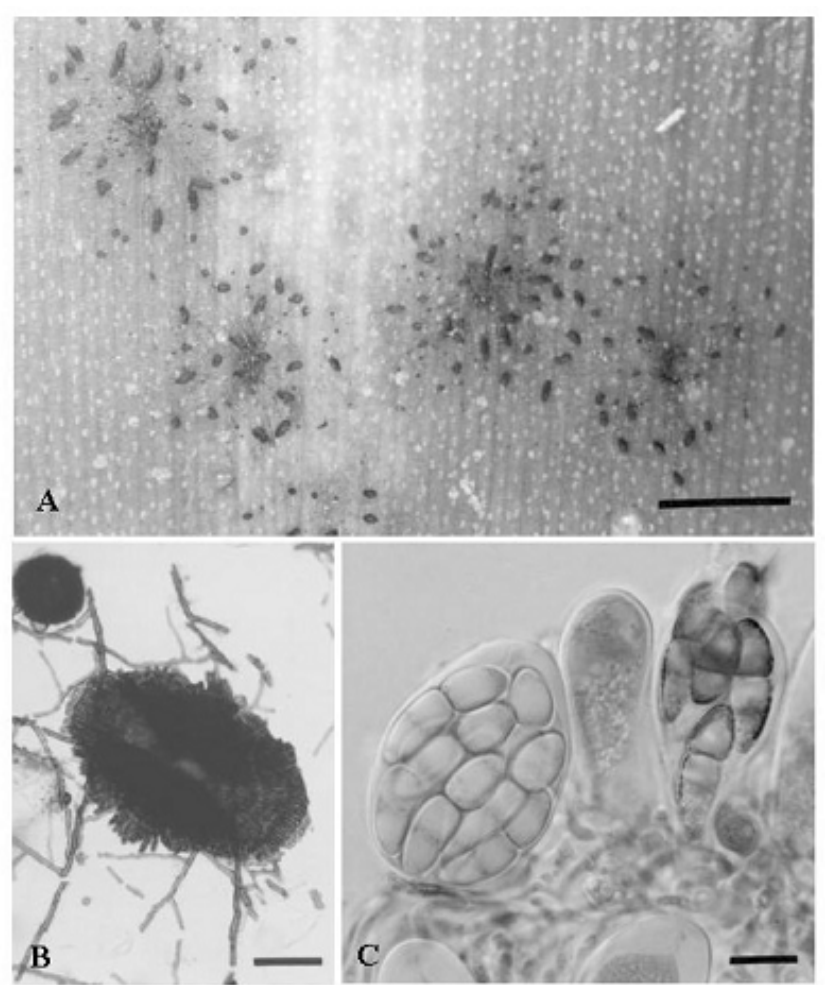

Figura 1. Lembosia bromeliacearum var. stellulata. (A) ascocarpos arranjados em forma estrelar, típicos da variedade; (B) ascocarpo elíptico com deiscência por ostíolo longitudinal e (C) asco bitunicado, com ascósporos didimosporos. Barras: $(\mathrm{A})=3,0 \mathrm{~mm} ;(\mathrm{B})=50 \mu \mathrm{m} ;(\mathrm{C})=$ $10 \mu \mathrm{m}$. 